\title{
EARLY GENERATION SELECTION STRATEGY FOR YIELD AND YIELD COMPONENTS IN WHITE OAT
}

\author{
Giovani Benin ${ }^{1}$; Fernando Irajá Félix de Carvalho ${ }^{2 *}$; Antônio Costa de Oliveira ${ }^{2}$; Claudir \\ Lorencetti ${ }^{1}$; Igor Pires Valério ${ }^{3}$; Douglas André Mallmann Schmidt ${ }^{3}$; Irineu Hartwig ${ }^{3}$; Guilherme \\ Ribeiro $^{3}$; Eduardo Alano Vieira ${ }^{1}$; José Antonio Gonzales da Silva ${ }^{1}$ \\ ${ }^{1}$ UFPel/FAEM - Programa de Pós-Graduação em Agronomia/Fitomelhoramento. \\ ${ }^{2}$ UFPel/FAEM - Depto. de Fitotecnia - C.P. 354 - 96001-970 - Pelotas, RS - Brasil. \\ ${ }^{3}$ UFPEL/FAEM - Setor de Fitomelhoramento. \\ *Corresponding author <carvalho@ufpel.tche.br>
}

\begin{abstract}
Several studies have searched for higher efficiency on plant selection in generations bearing high frequency of heterozygotes. This work aims to compare the response of direct selection for grain yield, indirect selection through average grain weight and combined selection for higher yield potential and average grain weight of oat plants (Avena sativa L.), using the honeycomb breeding method. These strategies were applied in the growing seasons of 2001 and 2002 in $\mathrm{F}_{3}$ and $\mathrm{F}_{4}$ populations, respectively, in the crosses UPF 18 CTC 5, OR $2 \times$ UPF 7 and OR $2 \times$ UPF 18 . The ten best genetic combinations obtained for each cross and selection strategy were evaluated in greenhouse yield trials. Selection of plants with higher yield and average grain weight might be performed on early generations with high levels of heterozygosis. The direct selection for grain yield and indirect selection for average grain weight enabled to increase the average of characters under selection. However, genotypes obtained through direct selection presented lower average grain weight and those obtained through the indirect selection presented lower yield potential. Selection strategies must be run simultaneously to combine in only one genotype high yield potential and large grain weight, enabling maximum genetic gain for both characters.
\end{abstract}

Key words: Avena sativa L., selection method, heritability, single plant selection

\section{ESTRATÉGIA DE SELEÇÃo PRECOCE PARA RENDIMENTO DE GRÃOS E COMPONENTES DO RENDIMENTO EM AVEIA BRANCA}

\begin{abstract}
RESUMO: Vários trabalhos têm sido desenvolvidos buscando uma maior eficiência de seleção de plantas em gerações com alta freqüência de heterozigotos. Comparou-se a resposta da seleção direta para rendimento de grãos, seleção indireta baseada no peso médio de grãos e seleção combinada de plantas de plantas em aveia (Avena sativa L.) para superior potencial produtivo e peso médio de grãos, utilizando o método colméia. As estratégias foram aplicadas nas safras agrícolas de 2001 e 2002 em populações $F_{3}$ e $F_{4}$, respectivamente, nos cruzamentos UPF $18 \times$ TC 5, OR $2 \times$ UPF 7 e OR $2 \times$ UPF 18 . As dez melhores combinações genéticas obtidas para cada cruzamento e estratégia de seleção foram avaliadas em ensaios de rendimento de grãos na safra agrícola de 2003. A seleção de plantas de maior rendimento de grãos e peso médio de grãos pode ser feita ainda em gerações com alto nível de heterozigose. A seleção direta para rendimento de grãos e a indireta com base no peso médio de grãos possibilitaram elevar a média dos caracteres sob seleção, entretanto, os genótipos obtidos pela primeira estratégia apresentaram baixo peso médio de grãos enquanto àqueles obtidos pela segunda apresentaram baixo potencial produtivo. A seleção deve ser conduzida de forma simultânea, buscando-se maximizar em um só genótipo elevado potencial de rendimento de grãos e peso de grãos, possibilitando a obtenção de máximo progresso genético para ambos os caracteres.

Palavras-chave: Avena sativa L., método de seleção, herdabilidade, seleção de plantas
\end{abstract}

\section{INTRODUCTION}

Most agronomical important traits, including grain yield, have complex genetic inheritance, and require the use of relatively large populations for studying plant breeding. In self-pollinating, segregating populations, the frequency of individuals with all favorable alleles is reduced with generations (Ramalho et al., 1993). In addi- tion, genotype $\times$ environment interaction hampers selection, especially in adverse environments, as is the case of Pelotas, a locality situated at the extreme South of Brazil (Benin et al., 2003a). Therefore, obtaining genetic gain for the character grain yield, demands adoption of selection strategies which could minimize environmental effects and effectively select quantitative traits in early generations. 
Researchers have proposed alterations to minimize disadvantages of the current selection systems. For instance, Fasoulas $(1973 ; 1977)$ proposed an hexagonal plant spacing model which equalizes environmental influences on the phenotypic expression, that is, if all plants share the same environment, the selection is restricted to best performances relatively to the six nearest neighboring plants, enabling the application of high selection pressure in early generations with high heterozygote frequency, restricting selection solely to gene action.

Because environmental effects are smaller inside the honeycomb, phenotypic variance components and their interaction are null. Therefore, any observed genetic variance will correspond to the phenotypic variation. The efficiency of the honeycomb method in promoting genetic gains for grain yield was observed for wheat (Triticum aestivum L.) by Saadalla (1994), rye (Secale cereale, L.) by Kyriakou \& Fasoulas (1985), rice (Oryza sativa L.) by Ntanos \& Roupakias (2001), and oat by Benin et al. (2004).

Because of the need for harvesting and threshing of individual plants, the trait grain yield is difficult to quantify. Therefore, selection strategies for less complex traits, with higher heritability and good correlation with grain yield, may facilitate the selection in generations with high levels of heterozygotes. Some authors observed that several oats' yield components presented higher heritability than yield itself, and carried good correlation with yield (Caierão, 2000; Benin et al., 2003a, 2003b; Marchioro et al., 2003a). Therefore, the goal of this work was to evaluate selection efficiency for grain yield in oats through the honeycomb method of segregating populations, under three selection strategies: 1) direct selection for grain yield; 2) indirect selection for grain yield through average grain weight, and 3) simultaneous selection combining grain yield and average grain weight.

\section{MATERIAL AND METHODS}

The experiments were conducted in a field on the agricultural years of 2001-2003 in an Hapludult from the Pelotas, RS, Brazil. Six hundred individual $\mathrm{F}_{3}$ plants were evaluated for each obtained cross (UPF $18 \times$ CTC 5; OR $2 \times$ UPF 7 and OR $2 \times$ UPF 18 ), by sowing ten seeds of each plant on a $3 \mathrm{~m}$-long row, $0.3 \mathrm{~m}$ spaced within and between rows (Figure 1), following the design proposed by Fasoulas (1973). Plants were evaluated for leaf rust reaction (percentage of infected leaf area), plant height (distance between culms base and the top of the main panicle excluding awns, 21 days after anthesis; $\mathrm{cm}$ ) and vegetative cycle (period from the emergence of seedlings to the heading of the main panicle; days). All plants (parents and progeny) were harvested individually and number of panicle per plant $\left(\mathrm{NP}_{1}\right)$ and grain yield per plant $\left(\mathrm{GY}_{1}\right)$ were recorded. Panicle weight $\left(\mathrm{PW}_{1}\right)$, number of

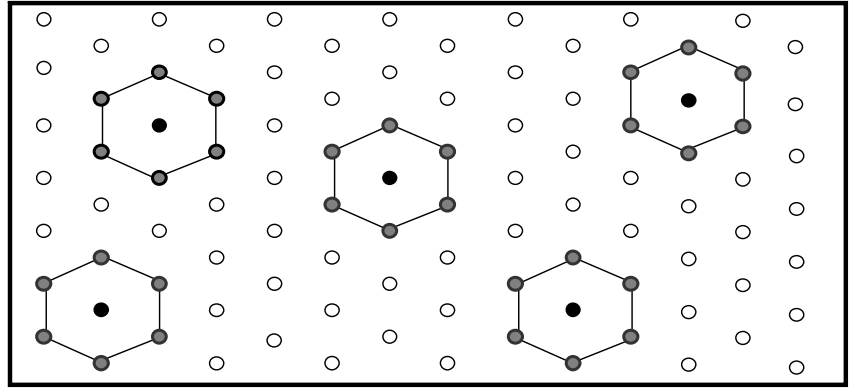

Figure 1 - Plant arrangement in the honeycomb method for selection of segregating populations. Hexagons represent groups of plants used to estimate comparative performances for each selected plant (central black dot).

grains per panicle $\left(\mathrm{NGP}_{1}\right)$ and the average grain weight $\left(\mathrm{AGW}_{1}\right.$; ratio between grain weight and number of grains) was recorded for the main panicle identified in the field.

Selection was performed based on the honeycomb superiority, that is, the selection of one plant for a given character higher than the neighboring six plants (Figure 1). Selection strategies used were: plant grain yield (PGY); average grain weight (AGW), and simultaneous selection for plants combining higher grain yield and average grain weight, i.e., combined selection (CS). Among the plants selected by either criterion, those with larger height, higher disease susceptibility and late cycle were eliminated.

Progenies of plants selected in 2001, for each cross and selection criterion, were sown in the field in October, 2002; experimental design, selection criteria and evaluations performed were the same. Seeds from the ten best plants selected in 2002, were sown in greenhouse for generation advance and seed production for the competition trials. Seeds were sown in December, 2002, in individual pots, eight to ten seeds per pot, each one set atop aluminum trays filled with water. Crop practices were performed as ordinarily recommended and needed.

Progenies from genotypes selected under each selection strategy, plus the check cultivars URS 21, UPF 18 , OR2 and CTC 5, were evaluated in three yield trials established in June, 2003, with seeds obtained in the greenhouse. Treatments were arranged in a randomized blocks experimental design $(n=3)$. The experimental plots consisted of five, $5.0 \mathrm{~m}$-long rows, spaced $0.2 \mathrm{~m}$; density of 300 viable seeds $\mathrm{m}^{-2}$. Variables evaluated were: a) grain yield $\left(\mathrm{GY}_{2} ; \mathrm{kg} \mathrm{ha}^{-1}\right)$, by the harvest of three central rows of each plot; $b$ ) number of panicles per linear meter $\left(\mathrm{NP}_{2}\right)$, by counting viable tiller number in two linear meters from each plot; c) hectoliter weight $\left(\mathrm{HW}_{2} ; \mathrm{kg}\right.$ $\mathrm{hL}^{-1}$ ), by weighing a known grain volume; d) panicle weight $\left(\mathrm{PW}_{2} ; \mathrm{g}\right)$, average weight of ten randomly-picked panicles; e) number of grains per panicle $\left(\mathrm{NGP}_{2}\right)$, the average number of grains of ten randomly-picked panicles; f) average grain weight $\left(\mathrm{AGW}_{2} ; \mathrm{g}\right)$, by dividing the weight of ten panicles by the number of grains. Also on 
the 2003 agricultural year, the progenies from genotypes evaluated in yield trials were planted as spaced plants, in $3.0 \mathrm{~m}$-long rows, spaced $0.3 \mathrm{~m}$, and evaluated for the same characters described.

Analysis of variance was performed and means comparisons were made using the Scott \& Knott test (Scott \& Knott, 1974). Heritability values were calculated using a regression genitor progeny (Carvalho et al., 2001). The association between characters was estimated by Pearson's correlation (Steel \& Torrie, 1980). All analyses were performed with Genes software (Cruz, 2001).

\section{RESULTS AND DISCUSSION}

Average yield characters of selected plants evaluated in the agricultural years 2001 and 2002 are presented in Table 1. It was possible to select plants with performance superior to their parents in all crosses. The strategy GYS allowed selection of plants with grain yield $\left(\mathrm{GY}_{1}\right)$ equal to $31(\mathrm{UPF} 18 \times \mathrm{CTC} 5), 35(\mathrm{OR} 2 \times \mathrm{UPF}$ $7)$ and $36 \mathrm{~g}$ (OR $2 \times \mathrm{UPF} 18)$. Results of combined selection (CS) for higher grain yield and average grain weight, average yield equal to 28 (UPF $18 \times$ CTC 5 ), 33 (OR $2 \times$ UPF 7) and $34 \mathrm{~g}$ (OR $2 \times \mathrm{UPF} 18)$, are comparable to those obtained for GYS. The average GY, from plants selected for average grain weight (AGWS) for the crosses UPF $18 \times$ CTC 5 (17), OR $2 \times$ UPF 7 (19) and OR $2 \times$ UPF 18 (23) were inferior to the average of plants selected by strategies GYS and CS. Strategy AGWS led to average grain weight of 0.039 (UPF $18 \times$ CTC 5),

Table 1 - Average values of yield traits evaluated in parental and selected plants through the honeycomb method in 2001 and 2002, using different selection strategies.

\begin{tabular}{lrrrrr}
\hline \multirow{2}{*}{$\begin{array}{l}\text { Selection } \\
\text { strategy }^{1}\end{array}$} & $\mathrm{NP}_{1}$ & $\mathrm{PW}_{1}$ & $\mathrm{NGP}_{1}$ & $\mathrm{AGW}_{1}$ & $\mathrm{GY}_{1}$ \\
\cline { 2 - 6 } & & $\mathrm{g}$ & & $-----\mathrm{g}$ & ------ \\
GYS & 10 & 4.6 & 133 & 0.029 & 31 \\
\hline AGWS & 6 & 4.3 & 91 & 0.039 & 17 \\
CS & 8 & 4.0 & 112 & 0.034 & 28 \\
GYS & 14 & 4.9 & 149 & 0.029 & 35 \\
AGWS & 10 & 4.4 & 93 & 0.041 & 19 \\
CS & 13 & 4.9 & 115 & 0.039 & 33 \\
GYS & 11 & 6.4 & 192 & 0.029 & 36 \\
AGWS & 8 & 5.4 & 124 & 0.038 & 23 \\
CS & 10 & 7.2 & 149 & 0.036 & 34 \\
\hline
\end{tabular}

${ }^{1} \mathrm{GYS}=$ selection for grain yield of individual plants; AGWS= selection for average grain weight; $\mathrm{CS}=$ combined selection.

${ }^{2} \mathrm{NP}_{1}=$ number of panicles per plant; $\mathrm{PW}_{1}=$ panicle weight; $\mathrm{NGP}_{1}=$ number of grains per panicle, $\mathrm{AGW}_{1}=$ average grain weight and $\mathrm{GY}_{1}=$ grain yield of individual plants.
0.041 (OR $2 \times \mathrm{UPF} 7)$ and $0.038 \mathrm{~g}$ (OR $2 \times \mathrm{UPF} 18)$; these results are similar to those obtained for CS.

The highest GY, obtained by strategies GYS and CS is related mainly to a higher expression of characters number of panicles per plant $\left(\mathrm{NP}_{1}\right)$ and number of grains per panicle $\left(\mathrm{NGP}_{1}\right)$ (Table 1). Benin et al. (2003b) observed that higher yield of individual grains resulted from higher expression of the character number of panicles per plant. On the other hand, evaluating the indirect selection for grain yield in oats, Chandhanamutta \& Frey (1973) observed that $80 \%$ of grain yield increase can be attributed to the number of grains per panicle and only $20 \%$ to grain weight, being both characters therefore responsible for panicle weight.

Correlation of 0.73 (GYS), 0.65 (AGWS) and 0.55 (CS) observed in Table 2 confirmed that a higher $\mathrm{GY}_{1}$ was associated to the higher $\mathrm{NP}_{1}$; these observations match reports of Petr \& Frey (1966) and Benin et al. (2003b). However, only in AGWS the character $\mathrm{NP}_{1}$ (spaced plants) had positive (0.54) correlation with $\mathrm{GY}_{2}$ (in yield plots), as a result of a significant correlation $(0.65)$ between $\mathrm{NP}_{1} \times \mathrm{NP}_{2}$ occurring only in this strategy (Table 3 ). The absence of correlation between $\mathrm{NP}_{1} \times \mathrm{RG}_{2}$ on strategies GYS (0.18) and CS (-0.21) can be explained by the absence of correlation between $\mathrm{NP}_{1} \times \mathrm{NP}_{2}$, because of the great potential of expression of this character under spaced plants, and its opposite behavior under competition. The same was not observed for strategy AGWS because average grain weight $\left(\mathrm{AGW}_{1}\right)$ was negatively associated to $\mathrm{NP}_{1}(\mathrm{r}=-0.47)$.

Table 2 - Correlation between individual plant grain yield of selected genotypes using the honeycomb method through different selection strategies, considering the average of crosses UPF $18 \times$ CTC 5 , OR $2 \times$ UPF 7 and OR $2 \times$ UPF 18 .

\begin{tabular}{|c|c|c|c|}
\hline \multirow{2}{*}{ Character $^{1}$} & \multicolumn{3}{|c|}{ Selection strategy ${ }^{2}$} \\
\hline & GYS & AGWS & $\mathrm{CS}$ \\
\hline $\mathrm{GY}_{1} \times \mathrm{AGW}_{1}$ & $0.23^{\mathrm{ns}}$ & $-0.10^{\mathrm{ns}}$ & $0.28^{\mathrm{ns}}$ \\
\hline $\mathrm{GY}_{1} \times \mathrm{NP}_{1}$ & $0.73 *$ & $0.65 *$ & $0.55^{*}$ \\
\hline $\mathrm{GY}_{1} \times \mathrm{PW}_{1}$ & $0.15^{\mathrm{ns}}$ & $0.47 *$ & $0.27^{\mathrm{ns}}$ \\
\hline $\mathrm{GY}_{1} \times \mathrm{NGP}_{1}$ & $0.12^{\mathrm{ns}}$ & $0.58 *$ & $0.23^{\mathrm{ns}}$ \\
\hline $\mathrm{AGW}_{1} \times \mathrm{NP}_{1}$ & $0.06^{\mathrm{ns}}$ & $-0.47 *$ & $-0.12^{\mathrm{ns}}$ \\
\hline $\mathrm{AGW}_{1} \times \mathrm{PW}_{1}$ & $0.25^{\text {ns }}$ & $0.19^{\text {ns }}$ & $0.13^{\mathrm{ns}}$ \\
\hline $\mathrm{AGW}_{1} \times \mathrm{NGP}_{1}$ & $-0.11^{\mathrm{ns}}$ & $-0.38^{\mathrm{ns}}$ & $-0.31^{\mathrm{ns}}$ \\
\hline $\mathrm{NP}_{1} \times \mathrm{PW}_{1}$ & $-0.36^{\mathrm{ns}}$ & $-0.10^{\mathrm{ns}}$ & $-0.46^{*}$ \\
\hline $\mathrm{NP}_{1} \times \mathrm{NGP}_{1}$ & $-0.35^{\mathrm{ns}}$ & $0.13^{\text {ns }}$ & $-0.30^{\mathrm{ns}}$ \\
\hline $\mathrm{PW}_{1} \times \mathrm{NGP}_{1}$ & $0.91 *$ & $0.82 *$ & $0.87 *$ \\
\hline
\end{tabular}

${ }^{1} \mathrm{NP}_{1}=$ number of panicles per plant; $\mathrm{PW}_{1}=$ panicle weight; $\mathrm{NGP}_{1}=$ number of grains per panicle; $\mathrm{AGW}_{1}=$ average grain weight and; $\mathrm{GY}_{1}=$ grain yield of individual plants.

${ }^{2} \mathrm{GYS}=$ selection for grain yield of individual plants; $\mathrm{AGWS}=$ selection for average grain weight; $\mathrm{CS}=$ combined selection.

${ }^{*} \alpha=0.05$; $\mathrm{t}$ test. ${ }^{\mathrm{ns}}$ non significant 
Character $\mathrm{NGP}_{1}$ was correlated with $\mathrm{GY}_{1}(0.58)$ only for strategy AGWS. That was not true for strategies GYS and CS because $\mathrm{NP}_{1}$ was negatively correlated with $\mathrm{NGP}_{1},(\mathrm{r}=-0.35$ and -0.30 , respectively $)$, even though these correlations were not significant (Table 2). This may also be the reason for absence of correlation between $\mathrm{GY}_{1}$ and $\mathrm{PW}_{1}$ in strategies GYS (0.15) and CS (0.27), and the positive correlation between these characters in the strategy AGWS (0.47).

Heritability values indicate the degree of genetic relationship between performance of parents and progeny, an important aspect for obtaining genetic progress on artificial selection (Table 4). Significant heritability

Table 3 - Correlation between individual plant grain yield component characters (1), and its correspondent performance in yield plots (2), in genotypes selected using the honeycomb method through different selection strategies, considering the average of crosses UPF $18 \times$ CTC 5 , OR $2 \times \mathrm{UPF}$ 7 and OR $2 \times$ UPF 18 .

\begin{tabular}{|c|c|c|c|}
\hline \multirow{2}{*}{ Character $^{1}$} & \multicolumn{3}{|c|}{ Selection strategy $^{2}$} \\
\hline & GYS & AGWS & $\mathrm{CS}$ \\
\hline $\mathrm{GY}_{1} \times \mathrm{GY}_{2}$ & $0.49 *$ & $0.60 *$ & $0.45^{*}$ \\
\hline $\mathrm{GY}_{1} \times \mathrm{PW}_{2}$ & $0.32^{\mathrm{ns}}$ & $0.41^{\mathrm{ns}}$ & $0.45 *$ \\
\hline $\mathrm{GY}_{1} \times \mathrm{NGP}_{2}$ & $0.39^{\text {ns }}$ & $0.48^{*}$ & $0.36^{\mathrm{ns}}$ \\
\hline $\mathrm{AGW}_{1} \times \mathrm{GY}_{2}$ & $0.01^{\text {ns }}$ & $-0.21^{\mathrm{ns}}$ & $0.46^{*}$ \\
\hline $\mathrm{AGW}_{1} \times \mathrm{AGW}_{2}$ & $0.05^{\text {ns }}$ & $0.70 *$ & $0.40 *$ \\
\hline $\mathrm{AGW}_{1} \times \mathrm{NP}_{2}$ & $-0.06^{\mathrm{ns}}$ & $-0.26^{\mathrm{ns}}$ & $0.37^{*}$ \\
\hline $\mathrm{AGW}_{1} \times \mathrm{PW}_{2}$ & $-0.17^{\mathrm{ns}}$ & $-0.24^{\mathrm{ns}}$ & $-0.22^{\mathrm{ns}}$ \\
\hline $\mathrm{AGW}_{1} \times \mathrm{NGP}_{2}$ & $-0.11^{\mathrm{ns}}$ & $-0.65^{*}$ & $-0.37 *$ \\
\hline $\mathrm{NP}_{1} \times \mathrm{GY}_{2}$ & $0.18^{\mathrm{ns}}$ & $0.54 *$ & $-0.21^{\mathrm{ns}}$ \\
\hline $\mathrm{NP}_{1} \times \mathrm{AGW}_{2}$ & $-0.17^{\mathrm{ns}}$ & $-0.07^{\mathrm{ns}}$ & $0.13^{\mathrm{ns}}$ \\
\hline $\mathrm{NP}_{1} \times \mathrm{NP}_{2}$ & $-0.02^{\mathrm{ns}}$ & $0.65^{*}$ & $0.03^{\mathrm{ns}}$ \\
\hline $\mathrm{NP}_{1} \times \mathrm{PW}_{2}$ & $0.34^{\mathrm{ns}}$ & $0.22^{\mathrm{ns}}$ & $-0.21^{\mathrm{ns}}$ \\
\hline $\mathrm{NP}_{1} \times \mathrm{NGP}_{2}$ & $0.41^{\mathrm{ns}}$ & $0.34^{\mathrm{ns}}$ & $-0.18^{\mathrm{ns}}$ \\
\hline $\mathrm{PW}_{1} \times \mathrm{GY}_{2}$ & $-0.22^{\mathrm{ns}}$ & $-0.05^{\mathrm{ns}}$ & $0.16^{\mathrm{ns}}$ \\
\hline $\mathrm{PW}_{1} \times \mathrm{AGW}_{2}$ & $0.18^{\mathrm{ns}}$ & $0.00^{\text {ns }}$ & $-0.28^{\mathrm{ns}}$ \\
\hline $\mathrm{PW}_{1} \times \mathrm{NP}_{2}$ & $-0.63 *$ & $-0.38^{\mathrm{ns}}$ & $-0.24^{\mathrm{ns}}$ \\
\hline $\mathrm{PW}_{1} \times \mathrm{PW}_{2}$ & $0.67 *$ & $0.45^{*}$ & $0.50 *$ \\
\hline $\mathrm{PW}_{1} \times \mathrm{NGP}_{2}$ & $0.58^{\mathrm{ns}}$ & $0.37^{\mathrm{ns}}$ & $0.58^{*}$ \\
\hline $\mathrm{NGP}_{1} \times \mathrm{GYP}_{2}$ & $-0.27^{\mathrm{ns}}$ & $-0.04^{\mathrm{ns}}$ & $0.03^{\mathrm{ns}}$ \\
\hline $\mathrm{NGP}_{1} \times \mathrm{AGW}_{2}$ & $0.06^{\mathrm{ns}}$ & $-0.38^{\mathrm{ns}}$ & $-0.27^{\mathrm{ns}}$ \\
\hline $\mathrm{NGP}_{1} \times \mathrm{NP}_{2}$ & $-0.68^{*}$ & $-0.32^{\mathrm{ns}}$ & $-0.39^{\text {ns }}$ \\
\hline $\mathrm{NGP}_{1} \times \mathrm{PW}_{2}$ & $0.64^{*}$ & $0.45^{*}$ & $0.58^{*}$ \\
\hline $\mathrm{NGP}_{1} \times \mathrm{NGP}_{2}$ & $0.57 *$ & $0.59 *$ & $0.65 *$ \\
\hline
\end{tabular}

${ }^{1} \mathrm{NP}_{1}=$ number of panicles per plant; $\mathrm{PW}_{1}=$ panicle weight; $\mathrm{NGP}_{1}=$ number of grains per panicle; $\mathrm{AGW}_{1}=$ average grain weight and; $\mathrm{GY}_{1}=$ grain yield of individual plants.

${ }^{2} \mathrm{GYS}=$ selection for grain yield of individual plants; $\mathrm{AGWS}=$ selection for average grain weight; $\mathrm{CS}=$ combined selection.

${ }^{*} \alpha=0.05 ; \mathrm{t}$ test. ${ }^{\mathrm{ns}}$ non significant values were recorded for $\mathrm{GY}_{1}$ in GYS (0.41 and 0.50), AGWS (0.21 and 0.27) and CS (0.46 and 0.49), for $\mathrm{F}_{3}$ $\mathrm{F}_{4}$ and $\mathrm{F}_{4}-\mathrm{F}_{5}$ generations, respectively. Heritability of $\mathrm{PMG}_{1}$ and $\mathrm{NP}_{1}$ show moderate association between the selected plants and their progeny, that is, it is possible to obtain genetic gain through selection. In these cases, reducing environmental variation and adopting a constant selection criterion, i.e. the honeycomb method, elicited higher selection efficiency, enabling plant selection for higher grain yield and average grain weight in highly heterozygous generations. In addition, different degrees of heritability on distinct selection strategies demands it to be considered in specific conditions. Heritability values tended to be higher at the second selection cycle, where the degree of homozygosis was increased, and resulted in more reliable selection response in generations $\mathrm{F}_{4}-\mathrm{F}_{5}$ in comparison to $\mathrm{F}_{3}-\mathrm{F}_{4}$ (Table 4). Because it is a function of phenotypic variance components, as well as of any other factor that can alter populations genetic variability, i.e., previously applied artificial selection, heritability values are valid for specific conditions and populations (Falconer and Mackay, 1996).

Differences were recorded $(P<0.01)$ for all evaluated characters, except number of panicles per linear meter $\left(\mathrm{NP}_{2}\right)$ for the crosses UPF $18 \times \mathrm{CTC} 5$ and OR $2 \times$ UPF 18 (Table 5). Variation coefficients ranged from 4.07 to $14.85 \%$, so estimations of assays were precise.

Table 4 - Heritability of grain yield and yield components of individual plant selection by the honeycomb method, using three selection strategies, considering average of crosses UPF $18 \times$ CTC 5, OR $2 \times$ UPF 7 and OR $2 \times$ UPF 18 .

\begin{tabular}{lcccc}
\hline \multirow{2}{*}{ Character $^{1}$} & \multirow{2}{*}{ Generation } & \multicolumn{3}{c}{ Selection strategy $^{2}$} \\
\cline { 2 - 5 } $\mathrm{NP}_{1}$ & $\mathrm{~F}_{3}-\mathrm{F}_{4}$ & $0.29^{*}$ & $0.17^{\mathrm{ns}}$ & $0.25^{*}$ \\
& $\mathrm{~F}_{4}-\mathrm{F}_{5}$ & $0.39^{*}$ & $0.25^{*}$ & $0.31^{*}$ \\
$\mathrm{RG}_{1}$ & $\mathrm{~F}_{3}-\mathrm{F}_{4}$ & $0.41^{*}$ & $0.21^{*}$ & $0.46^{*}$ \\
& $\mathrm{~F}_{4}-\mathrm{F}_{5}$ & $0.50^{*}$ & $0.27^{*}$ & $0.49^{*}$ \\
$\mathrm{PP}_{1}$ & $\mathrm{~F}_{3}-\mathrm{F}_{4}$ & $0.17^{\mathrm{ns}}$ & $0.11^{\mathrm{ns}}$ & $0.13^{\mathrm{ns}}$ \\
& $\mathrm{F}_{4}-\mathrm{F}_{5}$ & $0.27^{*}$ & $0.19^{*}$ & $0.11^{\mathrm{ns}}$ \\
$\mathrm{NGP}_{1}$ & $\mathrm{~F}_{3}-\mathrm{F}_{4}$ & $0.15^{\mathrm{ns}}$ & $0.01^{\mathrm{ns}}$ & $0.24^{*}$ \\
& $\mathrm{~F}_{4}-\mathrm{F}_{5}$ & $0.28^{\mathrm{ns}}$ & $0.28^{*}$ & $0.32^{*}$ \\
$\mathrm{PMG}_{1}$ & $\mathrm{~F}_{3}-\mathrm{F}_{4}$ & $0.42^{*}$ & $0.37^{*}$ & $0.36^{*}$ \\
& $\mathrm{~F}_{4}-\mathrm{F}_{5}$ & $0.51^{*}$ & $0.39^{*}$ & $0.43^{*}$ \\
\hline
\end{tabular}

${ }^{1} \mathrm{NP}_{1}=$ number of panicles per plant; $\mathrm{PW}_{1}=$ panicle weight; $\mathrm{NGP}_{1}=$ number of grains per panicle; $\mathrm{AGW}_{1}=$ average grain weight and; $\mathrm{GY}_{1}=$ grain yield of individual plants.

${ }^{2} \mathrm{GYS}=$ selection for grain yield of individual plants; AGWS= selection for average grain weight; $\mathrm{CS}=$ combined selection.

${ }^{*} \alpha=0.05 ; \mathrm{t}$ test. ${ }^{\text {ns }}$ non significant 
Differences among genotypes indicate variability among the studied characters. For the cross UPF 18 $\times$ CTC 5, grain yield varied from $3,492 \mathrm{~kg} \mathrm{ha}^{-1}$ (UFPel 03-01) to 1,900 $\mathrm{kg} \mathrm{ha}^{-1}$ (UFPel 03-30); cultivar URS 21, which produced $2,862 \mathrm{~kg} \mathrm{ha}^{-1}$, differed $(P<0.05)$ from genotypes included in the superior grain yield group. Grain yield of cross OR $2 \times$ UPF 7 ranged from 2,792 $\mathrm{kg} \mathrm{ha}^{-1}$ (UFPel 03-31) to 1,400 kg ha (UFPel 03-60), being the cultivar URS 21 included in the group of genotypes of superior grain yield (Table 7). Grain yield ranged from 3,400 kg ha ${ }^{-1}$ (UFPel 03-61) to $1,968 \mathrm{~kg}$ $\mathrm{ha}^{-1}$ (UFPel 03-90) for the cross OR $2 \times$ UPF 18, and there were no differences $(P>0.05)$ among the genotypes of the superior group and cultivar URS 21, which produced 3,048 $\mathrm{kg} \mathrm{ha}^{-1}$. All the crosses produced

Table 5 - Summary of ANOVA for the evaluated characters in yield trials for the crosses UPF $18 \times$ CTC 5 , OR $2 \times \mathrm{UPF} 7$ and OR $2 \times \mathrm{UPF} 18$.

\begin{tabular}{|c|c|c|}
\hline \multirow{2}{*}{ Character $^{1}$} & \multicolumn{2}{|c|}{ UPF $18 \times$ CTC 5} \\
\hline & MS Genotype & $\mathrm{CV}$ \\
\hline & & $\%$ \\
\hline $\mathrm{GY}_{2}$ & $178472.5^{*}$ & 14.85 \\
\hline $\mathrm{HW}_{2}$ & $434.67 *$ & 15.40 \\
\hline $\mathrm{AGW}_{2}$ & $2.12 *$ & 12.63 \\
\hline $\mathrm{NP}_{2}$ & $29.28^{\mathrm{ns}}$ & 11.96 \\
\hline $\mathrm{PW}_{2}$ & $0.68^{*}$ & 9.87 \\
\hline $\mathrm{NGP}_{2}$ & $612.3^{*}$ & 12.12 \\
\hline \multirow{3}{*}{ Character } & \multicolumn{2}{|c|}{ OR $2 \times$ UPF 7} \\
\hline & MS Genotype & $\mathrm{CV}$ \\
\hline & & $\%$ \\
\hline $\mathrm{GY}_{2}$ & $107474.23 *$ & 14.58 \\
\hline $\mathrm{HW}_{2}$ & $282.08 *$ & 11.15 \\
\hline $\mathrm{AGW}_{2}$ & $1.96^{*}$ & 8.11 \\
\hline $\mathrm{NP}_{2}$ & $42.78^{*}$ & 11.30 \\
\hline $\mathrm{PW}_{2}$ & $0.38^{*}$ & 7.86 \\
\hline $\mathrm{NGP}_{2}$ & $506.52 *$ & 6.20 \\
\hline \multirow{3}{*}{ Character } & \multicolumn{2}{|c|}{ OR $2 \times$ UPF 18} \\
\hline & MS Genotype & $\mathrm{CV}$ \\
\hline & & $\%$ \\
\hline $\mathrm{GY}_{2}$ & $84667.54 *$ & 13.24 \\
\hline $\mathrm{HW}_{2}$ & $222.39 *$ & 4.07 \\
\hline $\mathrm{AGW}_{2}$ & $1.68 *$ & 11.14 \\
\hline $\mathrm{NP}_{2}$ & $33.64^{\mathrm{ns}}$ & 10.50 \\
\hline $\mathrm{PW}_{2}$ & $0.53^{*}$ & 9.60 \\
\hline $\mathrm{NGP}_{2}$ & $604.26^{*}$ & 11.17 \\
\hline
\end{tabular}

${ }^{1} \mathrm{NP}_{2}=$ number of panicles per linear meter; $\mathrm{PW}_{2}=$ panicle weight (g); $\mathrm{NGP}_{2}=$ number of grains per panicle; $\mathrm{AGW}_{2}=$ average grain weight $(\mathrm{g}) ; \mathrm{HW}_{2}=$ hectoliter weight $\left(\mathrm{kg} \mathrm{hL}^{-1}\right) ; \mathrm{GY}_{1}=$ grain yield $\left(\mathrm{kg} \mathrm{ha}^{-1}\right)$.

${ }^{*} \alpha=0.05 ; \mathrm{F}$ test. ${ }^{\mathrm{ns}}$ non significant higher yielding genotypes in comparison to parental cultivars.

Genetic dissimilarity among the parents (Marchioro et al., 2003b) and combining ability (Lorencetti, 2004) lie among factors that may contribute for the detection of superior genotypes at the moment of selection. Among the ten best yielding genotypes of cross UPF $18 \times$ CTC 5 (Table 6), genotypes four, two and four were selected for GYS, AGWS and $\mathrm{CS}$, respectively. Among the ten best yielding genotypes of cross OR $2 \times$ UPF 7 (Table 7), genotypes five, one, and four were selected through GYS, AGWS and CS, respectively. Genotypes four, three, and three of cross OR $2 \times$ UPF 18 were selected through strategies GYS, AGWS and CS, respectively, out of the ten best yielding genotypes (Table 8).

Average yield of groups obtained by GYS and CS for UPF $18 \times$ CTC $5-2,870$ and $2,722 \mathrm{~kg} \mathrm{ha}^{-1}$, respectively - did not differ but were superior to the average of the group AGWS - 2,584 $\mathrm{kg} \mathrm{ha}^{-1}$ (Scott Knott test; $\alpha=0.05$ ) (Table 6). For cross OR $2 \times$ UPF 7 (Table $7)$, the group average for GYS $\left(2,450 \mathrm{~kg} \mathrm{ha}^{-1}\right)$ and CS $\left(2,368 \mathrm{~kg} \mathrm{ha}^{-1}\right)$ selections did not differ, but were superior to the AGWS group average $\left(2,018 \mathrm{~kg} \mathrm{ha}^{-1}\right)$. For the cross OR $2 \times$ UPF 18 (Table 8 ), group averages on grain yield for GYS $\left(2,768 \mathrm{~kg} \mathrm{ha}^{-1}\right)$ and CS $\left(2,706 \mathrm{~kg} \mathrm{ha}^{-1}\right)$ did not differ, but were superior to the AGWS group average $\left(2,634 \mathrm{~kg} \mathrm{ha}^{-1}\right)$. Therefore, possibility of genetic gain for grain yield through direct selection over the same character (GYS), and combined selection (CS), in relation to selection for average grain yield (AGWS) is higher.

Results herein observed do not match those obtained for wheat by Saadalla (1994), who observed that indirect selection for grain weight promoted higher genetic gain than direct selection for grain yield, as a result of the higher heritability of the character grain weight and its association to grain yield. Heritability values recorded for $A G W_{1}$, in generations $\mathrm{F}_{3}-\mathrm{F}_{4}$ and $\mathrm{F}_{4}-$ $\mathrm{F}_{5}$ (Table 4), also indicate that values observed for selected plant may direct the prediction of its progeny value. This selection effectiveness can be confirmed in Tables 6, 7 and 8: group average from strategies AGWS and CS presented higher average grain weight, superior to the group average for the strategy GYS. However, in despite of effectiveness of AGWS in breeding for average grain weight, it can not be used to identify higher yielding genotypes, because of negative $(-0.21)$ but non significant correlation between the average grain weight in spaced $\left(\mathrm{AGW}_{1}\right)$ and grain yield in yield plots $\left(\mathrm{GY}_{2}\right.$; Table 3). Regarding GYS, the correlation between $\mathrm{AGW}_{1}$ and $\mathrm{GY}_{2}$ was 0.01 . Because size and weight of grains are both important oat crop traits, using a selection strategy that considers, simultaneously, both char- 
acters is advisable. The correlation between $\mathrm{AGW}_{1}$ and $\mathrm{GY}_{2}(0.46)$ means that CS, the strategy that considered both characters at once, increased both average grain weight and grain yield simultaneously.
Stratifying selection environment increases selection efficiency. The indirect selection through the honeycomb method has proved being a viable strategy for the selection of potentially high-yielding genotypes. How-

Table 6 - Average grain yield and yield components of genotypes selected through the honeycomb method by different selection strategies for the UPF $18 \times$ CTC 5 cross.

\begin{tabular}{|c|c|c|c|c|c|c|c|}
\hline \multirow{2}{*}{ Genotypes } & \multicolumn{7}{|c|}{ Character $^{1}$} \\
\hline & Selection $^{2}$ & $\mathrm{GY}_{2}$ & $\mathrm{PW}_{2}$ & $\mathrm{AGW}_{2}$ & $\mathrm{NP}_{2}$ & $\mathrm{PW}_{2}$ & $\mathrm{NGP}_{2}$ \\
\hline UFPel 03-01 & GYS & $3492 a^{*}$ & $46 \mathrm{a}$ & $0.037 \mathrm{a}$ & $41 \mathrm{a}$ & $3.7 \mathrm{a}$ & $101 \mathrm{~b}$ \\
\hline UFPel 03-02 & $\mathrm{CS}$ & $3420 \mathrm{a}$ & $45 \mathrm{a}$ & $0.033 \mathrm{~b}$ & 38 a & $3.8 \mathrm{a}$ & $108 \mathrm{a}$ \\
\hline UFPel 03-03 & AGWS & 3414 a & $41 \mathrm{~b}$ & $0.044 \mathrm{a}$ & $36 \mathrm{a}$ & $3.5 \mathrm{a}$ & $72 \mathrm{c}$ \\
\hline UFPel 03-03 & GYS & 3378 a & $45 \mathrm{a}$ & $0.026 \mathrm{~b}$ & $43 \mathrm{a}$ & $2.6 \mathrm{~b}$ & $84 \mathrm{c}$ \\
\hline UFPel 03-05 & GYS & 3362 a & $40 \mathrm{c}$ & $0.029 \mathrm{~b}$ & $42 \mathrm{a}$ & $3.7 \mathrm{a}$ & $113 \mathrm{a}$ \\
\hline UFPel 03-06 & $\mathrm{CS}$ & $3290 \mathrm{a}$ & $36 \mathrm{~d}$ & $0.031 \mathrm{~b}$ & $42 \mathrm{a}$ & $3.4 \mathrm{a}$ & $93 \mathrm{~b}$ \\
\hline UFPel 03-07 & AGWS & 3256 a & $45 \mathrm{a}$ & $0.035 \mathrm{a}$ & 39 a & $3.6 \mathrm{a}$ & $94 \mathrm{~b}$ \\
\hline UFPel 03-08 & $\mathrm{CS}$ & $3210 \mathrm{a}$ & $46 \mathrm{a}$ & $0.035 \mathrm{a}$ & $40 \mathrm{a}$ & $3.0 \mathrm{~b}$ & $82 \mathrm{c}$ \\
\hline UFPel 03-09 & $\mathrm{CS}$ & 3154 a & $45 \mathrm{a}$ & $0.032 \mathrm{~b}$ & $35 \mathrm{a}$ & $4.3 \mathrm{a}$ & $117 \mathrm{a}$ \\
\hline UFPel 03-10 & GYS & 3142 a & $37 \mathrm{~d}$ & $0.028 \mathrm{~b}$ & $40 \mathrm{a}$ & $2.8 \mathrm{~b}$ & $89 \mathrm{c}$ \\
\hline UFPel 03-11 & AGWS & 3022 a & $42 \mathrm{~b}$ & $0.041 \mathrm{a}$ & $41 \mathrm{a}$ & $3.0 \mathrm{~b}$ & $59 \mathrm{c}$ \\
\hline UFPel 03-12 & GYS & $2976 \mathrm{~b}$ & $38 \mathrm{~d}$ & $0.029 \mathrm{~b}$ & $42 \mathrm{a}$ & $3.7 \mathrm{a}$ & $103 \mathrm{~b}$ \\
\hline URS 21 & - & $2862 \mathrm{~b}$ & $43 \mathrm{~b}$ & $0.037 \mathrm{a}$ & $47 \mathrm{a}$ & $2.6 \mathrm{~b}$ & $84 \mathrm{c}$ \\
\hline UFPel 03-13 & AGWS & $2860 \mathrm{~b}$ & $38 \mathrm{~d}$ & $0.032 \mathrm{~b}$ & $40 \mathrm{a}$ & $3.5 \mathrm{a}$ & $93 \mathrm{~b}$ \\
\hline UFPel 03-14 & $\mathrm{CS}$ & $2772 b$ & $43 \mathrm{~b}$ & 0.038 a & 38 a & $3.5 \mathrm{a}$ & $80 \mathrm{c}$ \\
\hline UFPel 03-15 & AGWS & $2778 \mathrm{~b}$ & $43 \mathrm{~b}$ & $0.039 \mathrm{a}$ & $36 \mathrm{a}$ & $3.7 \mathrm{a}$ & $70 \mathrm{c}$ \\
\hline UFPel 03-16 & GYS & $2768 \mathrm{~b}$ & $43 \mathrm{~b}$ & $0.033 \mathrm{~b}$ & $41 \mathrm{a}$ & $3.3 \mathrm{a}$ & $91 \mathrm{~b}$ \\
\hline UFPel 03-17 & AGWS & $2760 \mathrm{~b}$ & $35 \mathrm{~d}$ & $0.028 \mathrm{~b}$ & $42 \mathrm{a}$ & $3.7 \mathrm{a}$ & $97 \mathrm{~b}$ \\
\hline UFPel 03-18 & $\mathrm{CS}$ & $2698 \mathrm{~b}$ & $43 \mathrm{~b}$ & $0.034 \mathrm{a}$ & $37 \mathrm{a}$ & $2.9 \mathrm{~b}$ & $78 \mathrm{c}$ \\
\hline UFPel 03-19 & GYS & $2684 \mathrm{~b}$ & $42 \mathrm{~b}$ & $0.027 \mathrm{~b}$ & $41 \mathrm{a}$ & $4.0 \mathrm{a}$ & $113 \mathrm{a}$ \\
\hline UFPel 03-20 & GYS & $2572 \mathrm{~b}$ & $39 \mathrm{c}$ & $0.032 \mathrm{~b}$ & $47 \mathrm{a}$ & $2.7 \mathrm{~b}$ & $72 \mathrm{c}$ \\
\hline UFPel 03-21 & GYS & $2360 \mathrm{c}$ & $44 \mathrm{~b}$ & $0.028 \mathrm{~b}$ & $40 \mathrm{a}$ & $2.4 \mathrm{~b}$ & $74 \mathrm{c}$ \\
\hline UFPel 03-22 & $\mathrm{CS}$ & $2330 \mathrm{c}$ & $37 \mathrm{~d}$ & $0.033 \mathrm{~b}$ & $40 \mathrm{a}$ & $3.1 \mathrm{~b}$ & $78 \mathrm{c}$ \\
\hline UFPel 03-23 & $\mathrm{CS}$ & $2220 \mathrm{c}$ & $35 \mathrm{~d}$ & $0.032 \mathrm{~b}$ & $40 \mathrm{a}$ & $3.5 \mathrm{a}$ & $96 \mathrm{~b}$ \\
\hline UPF 18 & - & $2219 \mathrm{c}$ & $34 \mathrm{~d}$ & $0.034 \mathrm{a}$ & $42 \mathrm{a}$ & $2.9 \mathrm{~b}$ & $90 \mathrm{~b}$ \\
\hline UFPel 03-24 & AGWS & $2000 \mathrm{c}$ & $31 \mathrm{~d}$ & $0.030 \mathrm{~b}$ & $37 \mathrm{a}$ & $3.4 \mathrm{a}$ & $93 \mathrm{~b}$ \\
\hline UFPel 03-25 & $\mathrm{CS}$ & $2124 \mathrm{c}$ & $40 \mathrm{c}$ & $0.033 \mathrm{~b}$ & $46 \mathrm{a}$ & $2.9 \mathrm{~b}$ & $82 \mathrm{c}$ \\
\hline UFPel 03-26 & $\mathrm{CS}$ & $1994 \mathrm{c}$ & $40 \mathrm{c}$ & $0.033 \mathrm{~b}$ & $45 \mathrm{a}$ & $2.9 \mathrm{~b}$ & $83 \mathrm{c}$ \\
\hline UFPel 03-27 & GYS & $1972 \mathrm{c}$ & $38 \mathrm{c}$ & $0.028 \mathrm{~b}$ & $44 \mathrm{a}$ & $3.5 \mathrm{a}$ & $105 \mathrm{a}$ \\
\hline UFPel 03-28 & AGWS & $1928 \mathrm{c}$ & $34 \mathrm{~d}$ & $0.032 \mathrm{~b}$ & 39 a & $2.8 \mathrm{~b}$ & $81 \mathrm{c}$ \\
\hline UFPel 03-29 & AGWS & $1920 \mathrm{c}$ & $32 \mathrm{~d}$ & $0.028 \mathrm{~b}$ & $40 \mathrm{a}$ & $2.7 \mathrm{~b}$ & $78 \mathrm{c}$ \\
\hline CTC 5 & - & $1910 \mathrm{c}$ & $37 \mathrm{~d}$ & $0.031 \mathrm{~b}$ & $45 \mathrm{a}$ & $2.9 \mathrm{~b}$ & $91 \mathrm{~b}$ \\
\hline UFPel 03-30 & AGWS & $1900 \mathrm{c}$ & $32 \mathrm{~d}$ & $0.030 \mathrm{~b}$ & $43 \mathrm{a}$ & $2.9 \mathrm{~b}$ & $80 \mathrm{c}$ \\
\hline Means of group & & $\mathrm{GY}_{2}$ & $\mathrm{PW}_{2}$ & $\mathrm{AGW}_{2}$ & $\mathrm{NP}_{2}$ & $\mathrm{PW}_{2}$ & $\mathrm{NGP}_{2}$ \\
\hline GYS & & 2870 a & $41 \mathrm{a}$ & $0.029 \mathrm{~b}$ & $42 \mathrm{a}$ & $3.2 \mathrm{a}$ & $95 \mathrm{a}$ \\
\hline $\mathrm{CS}$ & & $2722 \mathrm{a}$ & $41 \mathrm{a}$ & $0.033 \mathrm{a}$ & $40 \mathrm{a}$ & $3.3 \mathrm{a}$ & $90 \mathrm{~b}$ \\
\hline AGWS & & $2584 \mathrm{~b}$ & $38 \mathrm{~b}$ & $0.034 \mathrm{a}$ & 39 a & $3.3 \mathrm{a}$ & $82 \mathrm{c}$ \\
\hline
\end{tabular}

${ }^{1} \mathrm{NP}_{2}=$ number of panicles per linear meter; $\mathrm{PW}_{2}=$ panicle weight $(\mathrm{g}) ; \mathrm{NGP}_{2}=$ number of grains per panicle; $\mathrm{AGW}_{2}=$ average grain weight (g); $\mathrm{HW}_{2}=$ hectoliter weight $\left(\mathrm{kg} \mathrm{hL}^{-1}\right) ; \mathrm{GY}_{1}=$ grain yield $\left(\mathrm{kg} \mathrm{ha}^{-1}\right)$.

${ }^{2} \mathrm{GYS}=$ selection for grain yield of individual plants; $\mathrm{AGWS}=$ selection for average grain weight; $\mathrm{CS}=$ combined selection.

*Means followed by the same letter do not differ; Scott Knott test, $\alpha=0.05$ 
ever, selection for plants with high yielding potential can lead to increasing number of grains per panicle and number of panicles per plant and, therefore decreasing average grain weight. Indirect selection based on average grain weight was efficient to improve the character itself, but was not effective in identifying potentially high-yielding genotypes. Selection strategies targeted at maximizing high yield potential and high grain weight in a single genotype will enable maximum genetic gain for both characters.

Table 7 - Average grain yield and yield components of genotypes selected through the honeycomb method by different selection strategies for the OR $2 \times$ UPF 7 cross.

\begin{tabular}{|c|c|c|c|c|c|c|c|}
\hline \multirow{2}{*}{ Genotypes } & \multicolumn{7}{|c|}{ Character $^{1}$} \\
\hline & Selection $^{2}$ & $\mathrm{GY}_{2}$ & $\mathrm{PW}_{2}$ & $\mathrm{AGW}_{2}$ & $\mathrm{NP}_{2}$ & $\mathrm{PW}_{2}$ & $\mathrm{NGP}_{2}$ \\
\hline UFPel 03-31 & SGY & $2792 a^{*}$ & $40 \mathrm{c}$ & $0.031 \mathrm{~b}$ & $38 \mathrm{~b}$ & $3.2 \mathrm{c}$ & $102 \mathrm{a}$ \\
\hline UFPel 03-32 & SGY & $2708 \mathrm{a}$ & $44 \mathrm{~b}$ & $0.031 \mathrm{~b}$ & $33 \mathrm{~b}$ & $2.9 \mathrm{~d}$ & $83 \mathrm{c}$ \\
\hline UFPel 03-33 & AGWS & 2686 a & $43 \mathrm{~b}$ & $0.029 \mathrm{~b}$ & $40 \mathrm{a}$ & $3.3 \mathrm{c}$ & $97 \mathrm{a}$ \\
\hline UFPel 03-34 & SGY & $2624 \mathrm{a}$ & $38 \mathrm{c}$ & $0.034 \mathrm{~b}$ & $37 \mathrm{~b}$ & $3.3 \mathrm{c}$ & $89 \mathrm{~b}$ \\
\hline UFPel 03-35 & SGY & $2620 \mathrm{a}$ & $37 \mathrm{c}$ & $0.031 \mathrm{~b}$ & $35 \mathrm{~b}$ & $3.2 \mathrm{c}$ & $85 \mathrm{~b}$ \\
\hline URS 21 & - & 2618 a & $42 \mathrm{~b}$ & $0.031 \mathrm{~b}$ & $44 \mathrm{a}$ & $2.8 \mathrm{~d}$ & $67 \mathrm{e}$ \\
\hline UFPel 03-36 & SGY & $2600 \mathrm{a}$ & $36 \mathrm{c}$ & $0.033 \mathrm{~b}$ & $35 \mathrm{~b}$ & $3.0 \mathrm{~d}$ & $85 \mathrm{c}$ \\
\hline UFPel 03-37 & $\mathrm{CS}$ & $2598 \mathrm{a}$ & $42 \mathrm{~b}$ & $0.032 \mathrm{~b}$ & $35 \mathrm{~b}$ & $3.4 \mathrm{c}$ & $97 \mathrm{a}$ \\
\hline UFPel 03-38 & $\mathrm{CS}$ & $2538 \mathrm{a}$ & $45 \mathrm{a}$ & $0.038 \mathrm{a}$ & $43 \mathrm{a}$ & $3.1 \mathrm{~d}$ & $85 \mathrm{c}$ \\
\hline UFPel 03-39 & CS & $2518 \mathrm{a}$ & $43 \mathrm{~b}$ & $0.031 \mathrm{~b}$ & $39 \mathrm{~b}$ & $3.6 \mathrm{~b}$ & $91 \mathrm{~b}$ \\
\hline UFPel 03-40 & $\mathrm{CS}$ & $2474 \mathrm{a}$ & $46 \mathrm{a}$ & $0.034 \mathrm{~b}$ & $45 \mathrm{a}$ & $2.9 \mathrm{~d}$ & $76 \mathrm{~d}$ \\
\hline UFPel 03-41 & AGWS & $2460 \mathrm{a}$ & $44 \mathrm{a}$ & $0.035 \mathrm{~b}$ & $43 \mathrm{a}$ & $3.0 \mathrm{~d}$ & $75 \mathrm{~d}$ \\
\hline UFPel 03-42 & $\mathrm{CS}$ & $2438 \mathrm{a}$ & $45 \mathrm{a}$ & $0.036 \mathrm{a}$ & $38 \mathrm{~b}$ & $3.3 \mathrm{c}$ & $86 \mathrm{~b}$ \\
\hline UFPel 03-43 & $\mathrm{CS}$ & $2342 \mathrm{a}$ & $44 \mathrm{a}$ & $0.039 \mathrm{a}$ & $36 \mathrm{~b}$ & $2.9 \mathrm{~d}$ & $64 \mathrm{e}$ \\
\hline UFPel 03-44 & AGWS & $2280 \mathrm{a}$ & $42 \mathrm{~b}$ & $0.037 \mathrm{a}$ & $34 \mathrm{~b}$ & $3.0 \mathrm{~d}$ & 68 e \\
\hline UFPel 03-45 & SGY & $2274 \mathrm{a}$ & $40 \mathrm{c}$ & $0.033 \mathrm{~b}$ & $41 \mathrm{a}$ & $3.1 \mathrm{~d}$ & $83 \mathrm{c}$ \\
\hline UFPel 03-46 & SGY & $2268 \mathrm{a}$ & $35 \mathrm{c}$ & $0.031 \mathrm{~b}$ & $43 \mathrm{a}$ & $3.0 \mathrm{~d}$ & $83 \mathrm{c}$ \\
\hline UFPel 03-47 & SGY & $2266 \mathrm{a}$ & $45 \mathrm{a}$ & $0.036 \mathrm{a}$ & $38 \mathrm{~b}$ & $3.3 \mathrm{c}$ & $86 \mathrm{~b}$ \\
\hline UFPel 03-48 & $\mathrm{CS}$ & $2264 \mathrm{a}$ & $43 \mathrm{~b}$ & $0.037 \mathrm{a}$ & $37 \mathrm{~b}$ & $3.7 \mathrm{~b}$ & $87 \mathrm{~b}$ \\
\hline UPF 7 & - & $2260 \mathrm{c}$ & $38 \mathrm{c}$ & $0.029 \mathrm{~b}$ & $43 \mathrm{a}$ & $2.6 \mathrm{~d}$ & $75 \mathrm{~d}$ \\
\hline UFPel 03-49 & CS & $2248 \mathrm{~b}$ & $43 \mathrm{~b}$ & $0.033 \mathrm{~b}$ & $42 \mathrm{a}$ & $2.4 \mathrm{e}$ & 63 e \\
\hline UFPel 03-50 & $\mathrm{CS}$ & $2246 \mathrm{~b}$ & $46 \mathrm{a}$ & $0.032 \mathrm{~b}$ & $33 \mathrm{~b}$ & $2.9 \mathrm{~d}$ & $75 \mathrm{~d}$ \\
\hline UFPel 03-51 & AGWS & $2224 \mathrm{~b}$ & $36 \mathrm{c}$ & $0.041 \mathrm{a}$ & $33 \mathrm{~b}$ & $4.1 \mathrm{a}$ & $97 \mathrm{a}$ \\
\hline UFPel 03-52 & SGY & $2198 \mathrm{~b}$ & $45 \mathrm{a}$ & $0.032 \mathrm{~b}$ & $34 \mathrm{~b}$ & $3.2 \mathrm{c}$ & $89 \mathrm{~b}$ \\
\hline UFPel 03-53 & AGWS & $2160 \mathrm{~b}$ & $44 \mathrm{a}$ & $0.030 \mathrm{~b}$ & $36 \mathrm{~b}$ & $3.4 \mathrm{c}$ & $86 \mathrm{~b}$ \\
\hline UFPel 03-54 & SGY & $2154 \mathrm{~b}$ & $46 \mathrm{a}$ & $0.032 \mathrm{~b}$ & $35 \mathrm{~b}$ & $3.2 \mathrm{c}$ & $90 \mathrm{~b}$ \\
\hline OR 2 & - & $2130 \mathrm{~b}$ & $41 \mathrm{~b}$ & $0.033 \mathrm{~b}$ & $41 \mathrm{a}$ & $3.0 \mathrm{~d}$ & $87 \mathrm{~b}$ \\
\hline UFPel 03-55 & AGWS & $2110 \mathrm{~b}$ & $41 \mathrm{~b}$ & $0.029 \mathrm{~b}$ & $38 \mathrm{~b}$ & $2.8 \mathrm{~d}$ & $78 \mathrm{~d}$ \\
\hline UFPel 03-56 & CS & $2004 \mathrm{~b}$ & $44 \mathrm{~b}$ & $0.033 \mathrm{~b}$ & $41 \mathrm{a}$ & $3.5 \mathrm{c}$ & $93 \mathrm{a}$ \\
\hline UFPel 03-57 & AGWS & $1976 \mathrm{~b}$ & $42 \mathrm{~b}$ & $0.032 \mathrm{~b}$ & $47 \mathrm{a}$ & $3.2 \mathrm{c}$ & $84 \mathrm{c}$ \\
\hline UFPel 03-58 & AGWS & $1462 \mathrm{~b}$ & $43 \mathrm{~b}$ & $0.042 \mathrm{a}$ & $33 \mathrm{~b}$ & $3.2 \mathrm{c}$ & $80 \mathrm{~d}$ \\
\hline UFPel 03-59 & AGWS & $1430 \mathrm{~b}$ & $40 \mathrm{c}$ & $0.040 \mathrm{a}$ & $30 \mathrm{~b}$ & $3.1 \mathrm{~d}$ & $75 \mathrm{~d}$ \\
\hline UFPel 03-60 & AGWS & $1400 \mathrm{~b}$ & $38 \mathrm{c}$ & $0.041 \mathrm{a}$ & $33 \mathrm{~b}$ & $4.1 \mathrm{a}$ & $90 \mathrm{~b}$ \\
\hline Means of group & & $\mathrm{GY}_{2}$ & $\mathrm{PW}_{2}$ & $\mathrm{AGW}_{2}$ & $\mathrm{NP}_{2}$ & $\mathrm{PW}_{2}$ & $\mathrm{NGP}_{2}$ \\
\hline GYS & & $2450 \mathrm{a}$ & $40 \mathrm{~b}$ & $0.032 \mathrm{~b}$ & $37 \mathrm{a}$ & $3.2 \mathrm{a}$ & $88 \mathrm{a}$ \\
\hline CS & & $2368 \mathrm{a}$ & $44 \mathrm{a}$ & $0.035 \mathrm{a}$ & 39 a & $3.2 \mathrm{a}$ & $81 \mathrm{~b}$ \\
\hline AGWS & & $2018 \mathrm{~b}$ & $42 \mathrm{~b}$ & $0.036 \mathrm{a}$ & $37 \mathrm{a}$ & $3.3 \mathrm{a}$ & $83 \mathrm{~b}$ \\
\hline
\end{tabular}

${ }^{1} \mathrm{NP}_{2}=$ number of panicles per linear meter; $\mathrm{PW}_{2}=$ panicle weight $(\mathrm{g}) ; \mathrm{NGP}_{2}=$ number of grains per panicle; $\mathrm{AGW}_{2}=$ average grain weight (g); $\mathrm{HW}_{2}=$ hectoliter weight $\left(\mathrm{kg} \mathrm{hL}^{-1}\right) ; \mathrm{GY}_{1}=$ grain yield $\left(\mathrm{kg} \mathrm{ha}^{-1}\right)$.

${ }^{2} \mathrm{GYS}=$ selection for grain yield of individual plants; $\mathrm{AGWS}=$ selection for average grain weight; $\mathrm{CS}=$ combined selection.

*Means followed by the same letter do not differ; Scott Knott test, $\alpha=0.05$ 
Table 8 - Average grain yield and yield components of genotypes selected through the honeycomb method by different selection strategies for the OR $2 \times$ UPF 18 cross.

\begin{tabular}{|c|c|c|c|c|c|c|c|}
\hline \multirow{2}{*}{ Genotypes } & \multicolumn{7}{|c|}{ Character $^{1}$} \\
\hline & Selection $^{2}$ & $\mathrm{GY}_{2}$ & $\mathrm{PW}_{2}$ & $\mathrm{AGW}_{2}$ & $\mathrm{NP}_{2}$ & $\mathrm{PW}_{2}$ & $\mathrm{NGP}_{2}$ \\
\hline UFPel 03-61 & AGWS & $3400 a^{*}$ & $42 \mathrm{~b}$ & $0.031 \mathrm{a}$ & $41 \mathrm{a}$ & $4.2 \mathrm{a}$ & $130 \mathrm{a}$ \\
\hline UFPel 03-62 & AGWS & 3380 a & $47 \mathrm{a}$ & $0.028 \mathrm{~b}$ & $43 \mathrm{a}$ & $3.6 \mathrm{~b}$ & $103 \mathrm{~b}$ \\
\hline UFPel 03-63 & GYS & 3174 a & $42 \mathrm{~b}$ & $0.027 \mathrm{~b}$ & $48 \mathrm{a}$ & $4.2 \mathrm{a}$ & $131 \mathrm{a}$ \\
\hline UFPel 03-64 & GYS & 3080 a & $44 \mathrm{~b}$ & $0.034 \mathrm{a}$ & $41 \mathrm{a}$ & $3.6 \mathrm{~b}$ & $115 \mathrm{a}$ \\
\hline URS 21 & - & 3048 a & $44 \mathrm{~b}$ & $0.035 \mathrm{a}$ & $37 \mathrm{a}$ & $4.3 \mathrm{a}$ & $82 \mathrm{c}$ \\
\hline UFPel 03-65 & $\mathrm{CS}$ & 2936 a & $45 \mathrm{~b}$ & $0.029 \mathrm{~b}$ & $43 \mathrm{a}$ & $3.7 \mathrm{~b}$ & $111 \mathrm{~b}$ \\
\hline UFPel 03-66 & $\mathrm{CS}$ & 2928 a & $48 \mathrm{a}$ & $0.028 \mathrm{~b}$ & $39 a$ & $3.7 \mathrm{~b}$ & $121 \mathrm{a}$ \\
\hline UFPel 03-67 & GYS & 2828 a & $43 \mathrm{~b}$ & $0.029 \mathrm{~b}$ & $46 \mathrm{a}$ & $3.0 \mathrm{~b}$ & $94 \mathrm{c}$ \\
\hline UFPel 03-68 & GYS & 2816 a & $46 \mathrm{a}$ & $0.029 \mathrm{~b}$ & $48 \mathrm{a}$ & $4.6 \mathrm{a}$ & $127 \mathrm{a}$ \\
\hline UFPel 03-69 & $\mathrm{CS}$ & $2784 \mathrm{a}$ & $48 \mathrm{a}$ & $0.028 \mathrm{~b}$ & $40 \mathrm{a}$ & $3.6 \mathrm{~b}$ & $107 \mathrm{~b}$ \\
\hline UFPel 03-70 & AGWS & $2780 \mathrm{a}$ & $44 \mathrm{~b}$ & $0.025 \mathrm{~b}$ & $42 \mathrm{a}$ & $3.1 \mathrm{~b}$ & $92 \mathrm{c}$ \\
\hline UFPel 03-71 & AGWS & $2768 \mathrm{a}$ & $48 \mathrm{a}$ & $0.028 \mathrm{~b}$ & $38 \mathrm{a}$ & $4.2 \mathrm{a}$ & $131 \mathrm{a}$ \\
\hline UFPel 03-72 & GYS & $2764 \mathrm{a}$ & $47 \mathrm{a}$ & $0.023 \mathrm{c}$ & $36 \mathrm{a}$ & $3.5 \mathrm{~b}$ & $120 \mathrm{a}$ \\
\hline UFPel 03-73 & GYS & $2760 \mathrm{a}$ & $48 \mathrm{a}$ & $0.025 \mathrm{~b}$ & $39 \mathrm{a}$ & $3.7 \mathrm{~b}$ & $127 \mathrm{a}$ \\
\hline UFPel 03-74 & AGWS & $2750 \mathrm{a}$ & $46 \mathrm{a}$ & $0.026 \mathrm{~b}$ & $36 \mathrm{a}$ & $4.1 \mathrm{a}$ & 129 a \\
\hline UFPel 03-75 & AGWS & $2740 \mathrm{a}$ & $44 \mathrm{~b}$ & $0.025 \mathrm{c}$ & $39 \mathrm{a}$ & $3.0 \mathrm{~b}$ & $96 \mathrm{~b}$ \\
\hline UFPel 03-76 & AGWS & $2726 a$ & $48 \mathrm{a}$ & $0.027 \mathrm{~b}$ & $43 \mathrm{a}$ & $3.2 \mathrm{~b}$ & $94 \mathrm{c}$ \\
\hline UFPel 03-77 & $\mathrm{CS}$ & $2690 \mathrm{a}$ & $43 \mathrm{~b}$ & $0.032 \mathrm{a}$ & $40 \mathrm{a}$ & $4.4 \mathrm{a}$ & $125 \mathrm{a}$ \\
\hline UFPel 03-78 & $\mathrm{CS}$ & $2686 a$ & $38 \mathrm{c}$ & $0.030 \mathrm{a}$ & $37 \mathrm{a}$ & $3.7 \mathrm{~b}$ & 119 a \\
\hline UFPel 03-79 & $\mathrm{CS}$ & $2654 \mathrm{~b}$ & $42 \mathrm{~b}$ & $0.031 \mathrm{a}$ & $41 \mathrm{a}$ & $3.5 \mathrm{~b}$ & $100 \mathrm{~b}$ \\
\hline UFPel 03-80 & $\mathrm{CS}$ & $2636 \mathrm{~b}$ & $44 \mathrm{~b}$ & $0.029 \mathrm{~b}$ & $44 \mathrm{a}$ & $3.5 \mathrm{~b}$ & $99 \mathrm{~b}$ \\
\hline UFPel 03-81 & $\mathrm{CS}$ & $2566 \mathrm{~b}$ & $43 \mathrm{~b}$ & $0.031 \mathrm{a}$ & $42 \mathrm{a}$ & $4.1 \mathrm{a}$ & $106 \mathrm{~b}$ \\
\hline UFPel 03-82 & $\mathrm{CS}$ & $2500 \mathrm{~b}$ & $44 \mathrm{~b}$ & $0.031 \mathrm{a}$ & $41 \mathrm{a}$ & $3.4 \mathrm{~b}$ & $103 \mathrm{~b}$ \\
\hline UFPel 03-83 & GYS & $2480 \mathrm{~b}$ & $45 \mathrm{~b}$ & $0.030 \mathrm{a}$ & $39 a$ & $3.5 \mathrm{~b}$ & $105 \mathrm{~b}$ \\
\hline UFPel 03-84 & GYS & $2478 \mathrm{~b}$ & $42 \mathrm{~b}$ & $0.030 \mathrm{a}$ & $36 a$ & $3.8 \mathrm{~b}$ & $109 \mathrm{~b}$ \\
\hline UPF 18 & - & $2419 \mathrm{~b}$ & $39 \mathrm{~d}$ & $0.031 \mathrm{a}$ & $38 \mathrm{a}$ & $3.1 \mathrm{~b}$ & $100 \mathrm{~b}$ \\
\hline UFPel 03-85 & AGWS & $2400 \mathrm{~b}$ & $43 \mathrm{~b}$ & $0.026 \mathrm{~b}$ & 39 a & $4.2 \mathrm{a}$ & $100 \mathrm{~b}$ \\
\hline UFPel 03-86 & AGWS & $2380 \mathrm{~b}$ & $39 \mathrm{~b}$ & $0.025 \mathrm{c}$ & $37 \mathrm{a}$ & $4.1 \mathrm{a}$ & $98 \mathrm{~b}$ \\
\hline OR 2 & - & $2465 \mathrm{c}$ & $39 \mathrm{~d}$ & $0.030 \mathrm{a}$ & $42 \mathrm{a}$ & $3.0 \mathrm{~b}$ & $99 \mathrm{~b}$ \\
\hline UFPel 03-87 & AGWS & $2356 \mathrm{~b}$ & $42 \mathrm{~b}$ & $0.029 \mathrm{~b}$ & $39 \mathrm{a}$ & $3.0 \mathrm{~b}$ & $91 \mathrm{~b}$ \\
\hline UFPel 03-88 & GYS & $2340 \mathrm{~b}$ & $36 \mathrm{c}$ & $0.031 \mathrm{a}$ & $41 \mathrm{a}$ & $3.8 \mathrm{~b}$ & $106 \mathrm{~b}$ \\
\hline UFPel 03-89 & GYS & $2332 \mathrm{~b}$ & $36 \mathrm{c}$ & $0.032 \mathrm{a}$ & $40 \mathrm{a}$ & $3.9 \mathrm{a}$ & $121 \mathrm{a}$ \\
\hline UFPel 03-90 & $\mathrm{CS}$ & $1968 \mathrm{~b}$ & $36 \mathrm{c}$ & $0.026 \mathrm{~b}$ & $40 \mathrm{a}$ & $3.1 \mathrm{~b}$ & $97 \mathrm{~b}$ \\
\hline Means of group & & $\mathrm{GY}_{2}$ & $\mathrm{PW}_{2}$ & $\mathrm{AGW}_{2}$ & $\mathrm{NP}_{2}$ & $\mathrm{PW}_{2}$ & $\mathrm{NGP}_{2}$ \\
\hline GYS & & $2768 \mathrm{a}$ & $45 \mathrm{a}$ & $0.027 \mathrm{~b}$ & $40 \mathrm{a}$ & $3.8 \mathrm{a}$ & $110 \mathrm{~b}$ \\
\hline $\mathrm{CS}$ & & $2706 \mathrm{a}$ & $43 \mathrm{~b}$ & $0.029 \mathrm{a}$ & $41 \mathrm{a}$ & $3.8 \mathrm{a}$ & $116 \mathrm{a}$ \\
\hline AGWS & & $2634 \mathrm{~b}$ & $44 \mathrm{~b}$ & $0.030 \mathrm{a}$ & $41 \mathrm{a}$ & $3.7 \mathrm{a}$ & $109 \mathrm{~b}$ \\
\hline
\end{tabular}

${ }^{1} \mathrm{NP}_{2}=$ number of panicles per linear meter; $\mathrm{PW}_{2}=$ panicle weight $(\mathrm{g}) ; \mathrm{NGP}_{2}=$ number of grains per panicle; $\mathrm{AGW}_{2}=$ average grain weight (g); $\mathrm{HW}_{2}=$ hectoliter weight $\left(\mathrm{kg} \mathrm{hL}^{-1}\right) ; \mathrm{GY}_{1}=$ grain yield $\left(\mathrm{kg} \mathrm{ha}^{-1}\right) .{ }^{2} \mathrm{GYS}=$ selection for grain yield of individual plants; AGWS $=$ selection for average grain weight; $\mathrm{CS}=$ combined selection. *Means followed by the same letter do not differ; Scott Knott test, $\alpha=0.05$

\section{REFERENCES}

BENIN, G.; CARVALHO, F.I.F de; OLIVEIRA, A.C.; FLOSS, E.L.; LORENCETTI, C.; MARCHIORO, V.S.; SILVA, J.A.G. Implicações do ambiente sobre o rendimento de grãos em aveia e suas influências sobre estimativas de parâmetros genéticos. Revista Brasileira de Agrociência, v.9, p.207-214, 2003a.

BENIN, G.; CARVALHO, F.I.F. de; OLIVEIRA, A.C.; MARCHIORO, V.S.; LORENCETTI, C.; KUREK, A.J.; SILVA, J.A.G.; CARGININ; A.; SIMIONI, D. Estimativas de correlações e coeficientes de trilha como critérios de seleção para rendimento de grãos em aveia. Revista Brasileira de Agrociência, v.9, p.9-16, 2003 b.
BENIN, G.; CARVALHO, F.I.F. de; OLIVEIRA, A.C.; SILVA, J.A.G.; LORENCETTI, C.; MAIA, M.B.; MARCHIORO, V.S.; FREITAS, F.; HARTWIG, I. Uma proposta de seleção para caracteres quantitativos e qualitativos em aveia. Ciência Rural, v.34, p.701-706, 2004.

CAIERÃO, E. Peso de panícula como critério de seleção indireta para rendimento de grãos em aveia. Pelotas: UFPel, 2000. 180p. (Dissertação - Mestrado).

CARVALHO, F.I.F.; SILVA, S.A.; KUREK, A.J.; MARCHIORO, V.S. Estimativas e implicações da herdabilidade como estratégia de seleção. Pelotas: Editora e Gráfica da UFPel, 2001. 99p.

CHANDHANAMUTTA, P.; FREY, K.J. Indirect mass selection for grain yield in oat populations. Crop Science, v.13, p.470-473, 1973.

Sci. Agric. (Piracicaba, Braz.), v.62, n.4, p.357-365, July/Aug. 2005 
CRUZ, C.D. Programa genes: aplicativo computacional em genética e estatística. Viçosa: UFV, 2001. 648p.

FALCONER, D.S.; MACKAY, T.F. Introduction to quantitative genetics. 4.ed. London: Longman Group, 1996. 464p.

FASOULAS, A. A new approach to breeding superior yielding varieties. Thessalonika: Aristotelian University of Thessalonika, Department of Genetic and Plant Breeding, 1973. 42p. (Publication, 3).

FASOULAS, A. Field designs for genotypic evaluation and selection. Thessalonika: Aristotelian University of Thessalonika, Department of Genetic and Plant Breeding, 1977. (Publication, 7).

KYRIAKOU, D.T.; FASOULAS, A.C. Effects of competition and selection pressure on yield response in winter rye (Secale cereale L.). Euphytica, v.34, p.883-895, 1985.

LORENCETTI, C. Capacidade combinatória de genitores e suas implicações no desenvolvimento de progênies superiores em aveia (Avena sativa L.). Pelotas: UFPel, 2004. 102p. (Tese - Doutorado).

MARCHIORO, V.S.; CARVALHO, F.I.F.; OLIVIRA, A.C.; LORENCETTI, C.; BENIN, G.; SILVA, J.A.G.; KUREK, A.J.; HARTWIG, I. Herdabilidade e correlações para caracteres de panícula em populações segregantes de aveia. Revista Brasileira de Agrociência, v.9, p.323328, 2003a.

MARCHIORO, V.S.; CARVALHO, F.I.F.; OLIVEIRA, A.C.; CRUZ, P.J.; LORENCETTI, C.; BENIN, G.; SILVA, J.A.G.; SCHMIDT, D.A.M. Dissimilaridade genética entre genótipos de aveia. Ciência e Agrotécnica, v.27, p.258-294, 2003 b.
MORENO, J.A. Clima do Rio Grande do Sul. Secção de Geografia. Porto Alegre: Secretaria da Agricultura, 1961. 42p.

NTANOS, D.A.; ROUPAKIAS, D.G. Comparative efficiency of two breeding methods for yield and quality in rice. Crop Science, v.41, p.345350, 2001.

PETR, F.C.; FREY, K.J. Genotypic correlations, dominance and heritability of quantitative characters in oats. Crop Science, v.6, p.259-262, 1966.

RAMALHO, M.A.P.; SANTOS, J.B.; ZIMMERMANN, M.J.O. Genética quantitativa em plantas autógamas: aplicações no melhoramento do feijoeiro. Goiânia: UFG, 1993. 271p.

SAADALLA, M.M. Response to early-generation for yield and yield components in wheat. Cereal Research Communications, v.22, 187 193, 1994.

SCOTT, A.J.; KNOTT, M.A. Cluster analysis methods for grouping means in the analysis of variance. Biometrics, v.30, p.507-512, 1974.

STEEL, R.G.D.; TORRIE, J.L. Principles and procedures of statistics. New York: McGraw Hill, 1980. 481p.

Received October 10, 2004

Accepted February 01, 2005 